\title{
Simultaneous development of Kawasaki disease following acute human adenovirus infection in monozygotic twins: A case report
}

Sayaka Fukuda ${ }^{1 *}$, Shuichi Ito ${ }^{2}$, Maya Fujiwara ${ }^{1}$, Jun Abe $^{3}$, Nozomu Hanaoka ${ }^{4}$, Tsuguto Fujimoto ${ }^{4}$ and Hiroshi Katsumori ${ }^{1}$

\begin{abstract}
Background: The etiology of Kawasaki disease (KD) remains unknown. However, many studies have suggested that specific genetic factors and/or some infectious agents underlie the onset of KD. Previous studies have suggested that human adenovirus (HAdV) is one of the triggering pathogens of KD. Here, we report monozygotic twin boys who sequentially developed KD in conjunction with acute HAdV type 3 (HAdV-3) infection.

Case presentation: The patients were four-year-old monozygotic twin boys. The elder brother developed a high fever and was diagnosed with HAdV infection with an immunochromatographic kit for HAdV (IC-kit). He was transferred to our institute after persistent fever for 7 days. On admission, he already fulfilled all the diagnostic

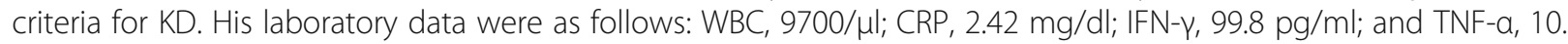
$9 \mathrm{pg} / \mathrm{ml}$. He received intravenous immunoglobulin (IVIG) and aspirin and responded well, with no coronary artery abnormalities. The younger brother, who was also IC-kit-positive, was hospitalized on the same day as his elder

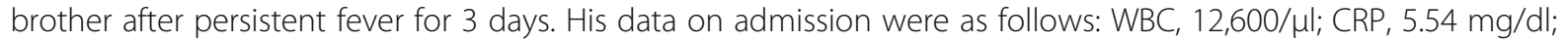
IFN- $\gamma, 105.0 \mathrm{pg} / \mathrm{ml}$; and TNF-a, $33.6 \mathrm{pg} / \mathrm{ml}$. Although he developed all of the typical KD symptoms by day 4 , his fever subsided spontaneously on day 6 without IVIG or aspirin. However, he developed a dilation of the coronary artery in the region of the left circumflex artery bifurcation on day 10 . His coronary artery dilation had resolved 3 months after onset. HAdV-3 DNA was detected with PCR in stool samples from both patients, and HAdV3 was isolated from the younger brother's stool sample. Serum neutralizing antibodies to AdV3 were also significantly elevated in both patients, suggesting seroconversion.
\end{abstract}

Conclusions: There have been few reports of the simultaneous development of KD in monozygotic twins. Notably, both twins had an acute HAdV-3 infection immediately before they developed KD. These cases strongly suggest that KD was triggered by HAdV-3 infection, and they indicate that specific immune responses to some pathogens (such as HAdV-3), arising from genetic susceptibility, play a critical role in the pathogenesis of KD.

Keywords: Kawasaki disease, Human adenovirus, Monozygotic twins, Pathogenesis, Genetic susceptibility

\footnotetext{
* Correspondence: sfmk369@yahoo.co.jp

'Department of Pediatrics, Kawakita General Hospital, 1-7-3 Asagaya-kita,

Suginami-ku, Tokyo, Japan

Full list of author information is available at the end of the article
} 


\section{Background}

Kawasaki disease (KD) is an acute systemic vasculitis syndrome, first reported by Dr. Tomisaku Kawasaki in 1967 [1]. Although its etiology remains unknown, specific genetic factors and/or some infectious agents may underlie the onset of KD [2,3]. Previous studies have shown that human adenovirus (HAdV) might be one of the pathogens that triggers KD [4]. Here, we describe a case report of monozygotic twins who simultaneously developed KD after an acute HAdV type 3 (HAdV-3) infection, which was confirmed by PCR-sequencing, virus isolation, and seroconversion. Our case is the first report of KD associated with monozygotic twins who suffered a HAdV-3 infection, and it supports the hypothesized pathogenesis described above.

\section{Case presentation}

The patients were four-year-old monozygotic twin boys who had previously been healthy and had no family history of KD.

\section{Case 1: Elder brother}

The elder brother developed a high fever on day 1 of his illness and subsequently developed redness of the eyes, red cracked lips, strawberry tongue, erythema, swollen red palms and soles, and cervical lymphadenopathy. He was admitted to our hospital on the seventh day after fever onset. On admission, he met all six diagnostic criteria for KD and was also diagnosed with HAdV infection with a rapid test for AdV (Imunoace adeno, TAUNS Laboratories Inc. Shizuoka, Japan). His laboratory data were: white blood cells (WBC), 9700/ $\mu \mathrm{L}$ (neutrophil sequestration, 66.0\%); hematocrit, $38.8 \%$; platelet count, $35.7 \times 10^{4} / \mu \mathrm{L}$; albumin, $4.1 \mathrm{~g} / \mathrm{dL}$; total bilirubin, $0.5 \mathrm{mg} / \mathrm{dL}$; sodium, $130 \mathrm{mEq} / \mathrm{L}$; aspartate aminotransferase (AST), $31 \mathrm{IU} / \mathrm{L}$; alanine aminotransferase (ALT), $16 \mathrm{IU} / \mathrm{L}$; and C-reactive protein, (CRP) $2.4 \mathrm{mg} / \mathrm{dL}$. His serum cytokine profile was: granulocyte-colony stimulating factor (G-CSF), $384.0 \mathrm{pg} /$ $\mathrm{mL}$; interferon- $\gamma$ (IFN- $\gamma$ ), $99.8 \mathrm{pg} / \mathrm{mL}$; interleukin-6 (IL-6), 43.8 pg/mL; IL-8, 36.9 pg/mL; IL-18, 1200.6 pg/mL; tumor necrosis factor (TNF- $\alpha$ ), $10.9 \mathrm{pg} / \mathrm{mL}$; soluble tumor necrosis factor receptor 1 (sTNFR-1), $1106.9 \mathrm{pg} / \mathrm{mL}$; and sTNFR-2, 10,013.4 pg/mL (Table 1). The patient was immediately treated with $2 \mathrm{~g} / \mathrm{kg}$ intravenous immunoglobulin (IVIG) and aspirin. He responded well and achieved defervescence the next day, and all his symptoms disappeared promptly. Desquamation of the fingers was observed on day 12 of illness. He discharged on the 16th day of hospitalization (Fig. 1). A transthoracic echocardiography revealed no coronary artery abnormalities.

\section{Case 2: Younger brother}

The younger brother also presented with a high fever and redness of eyes 4 days after his elder brother's
Table 1 Patient laboratory data on admission

\begin{tabular}{lllll}
\hline & & (normal range) & Case 1 & Case 2 \\
\hline WBC & $/ \mu \mathrm{L}$ & & 9700 & 12,600 \\
Neut. & $\%$ & & 66.0 & 71.0 \\
HtC. & $\%$ & 38.8 & 36.8 \\
Plt. & $\times 10^{4} / \mu \mathrm{L}$ & & 35.7 & 39.2 \\
Albumin & $\mathrm{g} / \mathrm{dL}$ & & 4.14 & 4.33 \\
Tbil. & $\mathrm{mg} / \mathrm{dL}$ & & 0.5 & 0.6 \\
Na & $\mathrm{mEq} / \mathrm{L}$ & & 130.4 & 132.3 \\
AST & $\mathrm{IU} / \mathrm{L}$ & & 31 & 30 \\
ALT & $\mathrm{IU} / \mathrm{L}$ & & 16 & 13 \\
CRP & $\mathrm{mg} / \mathrm{dL}$ & & 2.42 & 5.54 \\
G-CSF & $\mathrm{pg} / \mathrm{mL}$ & $(<100 \mathrm{pg} / \mathrm{mL})$ & 384.0 & 511.0 \\
IFN- $\gamma$ & $\mathrm{pg} / \mathrm{mL}$ & $(<30 \mathrm{pg} / \mathrm{mL})$ & 99.8 & 105.0 \\
IL-6 & $\mathrm{pg} / \mathrm{mL}$ & $(<20 \mathrm{pg} / \mathrm{mL})$ & 43.8 & 37.6 \\
IL-8 & $\mathrm{pg} / \mathrm{mL}$ & $(<30 \mathrm{pg} / \mathrm{mL})$ & 36.9 & 33.5 \\
IL-18 & $\mathrm{pg} / \mathrm{mL}$ & $(<500 \mathrm{pg} / \mathrm{mL})$ & 1200.6 & 580.4 \\
TNFa & $\mathrm{pg} / \mathrm{mL}$ & $(<20 \mathrm{pg} / \mathrm{mL})$ & 10.9 & 33.6 \\
sTNFR-1 & $\mathrm{pg} / \mathrm{mL}$ & $(<500 \mathrm{pg} / \mathrm{mL})$ & 1106.9 & 736.4 \\
sTNFR-2 & $\mathrm{pg} / \mathrm{mL}$ & $(<5000 \mathrm{pg} / \mathrm{mL})$ & $10,013.4$ & 8063.8 \\
\hline WBC & & &
\end{tabular}

WBC white blood cells, Neut. neutrophil sequestration, Htc. hematocrit, Plt. platelet count, Tbil. total bilirubin, Na sodium, AST aspartate aminotransferase, $A L T$ alanine aminotransferase, CRP C-reactive protein, G-CSF granulocyte colony-stimulating factor, IFN- $\gamma$ interferon- $\gamma, I L-6,-8,-18$ interleukin- $6,-8,-18$, respectively, TNF- $a$ tumor necrosis factor,

sTNFR-1, --2 soluble tumor necrosis factor receptor 1,2 , respectively

symptom onset, and he then developed red cracked lips, strawberry tongue, and cervical lymphadenopathy on day 3. The patient was hospitalized on the same day as his elder brother after experiencing a persistent fever for 3 days, and a rapid test for HAdV was positive at this time. His laboratory data upon admission were: WBC, $12,600 / \mu \mathrm{L}$ (neutrophil sequestration, 65.1\%); hematocrit, $36.8 \%$; platelet count, $39.2 \times 10^{4} / \mu \mathrm{L}$; albumin, $4.3 \mathrm{~g} / \mathrm{dL}$; total bilirubin, $0.6 \mathrm{mg} / \mathrm{dL}$; sodium, $132 \mathrm{mEq} / \mathrm{L}$; AST, $30 \mathrm{IU} / \mathrm{L} ;$ ALT, $13 \mathrm{IU} / \mathrm{L}$; and CRP, $5.5 \mathrm{mg} / \mathrm{dL}$. His serum cytokine levels were: G-CSF, $511.0 \mathrm{pg} / \mathrm{mL}$; IFN- $\gamma$, 105.0 pg/mL; IL-6, 37.6 pg/mL; IL-8, 33.5 pg/mL; IL-18, $580.4 \mathrm{pg} / \mathrm{mL}$; TNF- $\alpha, 33.6 \mathrm{pg} / \mathrm{mL}$; sTNFR-1, $736.4 \mathrm{pg} /$ $\mathrm{mL}$; and sTNFR-2, $8063.8 \mathrm{pg} / \mathrm{mL}$ (Table 1). Unlike his brother, this patient met only three of the diagnostic criteria for KD upon admission, so we diagnosed him as having incomplete KD and did not treat him with IVIG or aspirin. On the day 5 of illness (2 days post-admission), the patient displayed all six symptoms of KD, but his fever spontaneously resolved on day 6 of illness without treatment (the patient received neither IVIG nor aspirin). After defervescence, all symptoms soon disappeared, and his laboratory data normalized. His CRP was $2.74 \mathrm{mg} / \mathrm{dL}$ on day 5 of illness and $0.22 \mathrm{mg} / \mathrm{dL}$ on day 10 of illness. On day 9 of illness, finger desquamation was observed. Unlike 

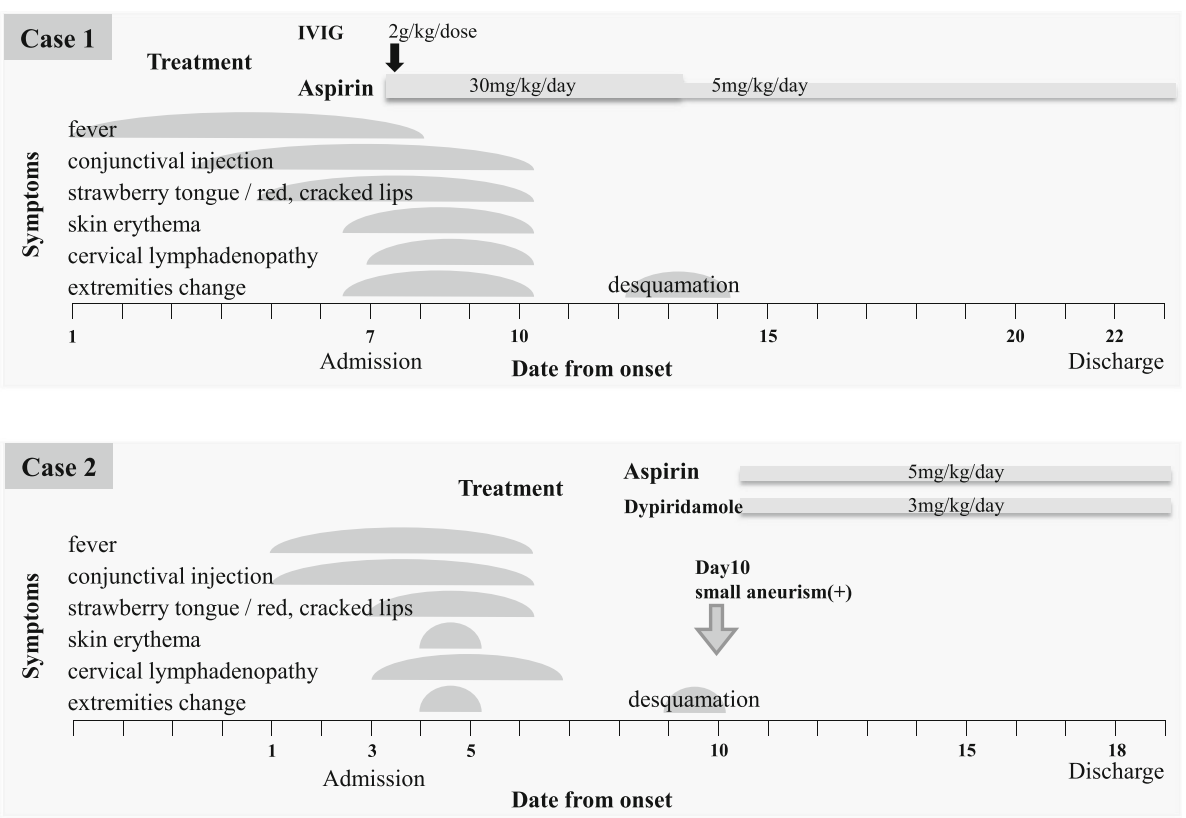

Fig. 1 Clinical course of the patients

his brother, this patient's echocardiography revealed a dilation of the left circumflex artery on day 10 of illness. We commenced treatment with $5 \mathrm{mg} / \mathrm{kg} /$ day of aspirin and $3 \mathrm{mg} / \mathrm{kg} /$ day of dipyridamole. He was discharged on the 16th day of hospitalization (Fig. 1). The maximum diameter of the coronary artery abnormality reached $3.9 \mathrm{~mm}$ ( $\mathrm{Z}$ score, 4.7 ), but the coronary artery abnormality resolved within 3 months of onset.

Fecal samples were collected from both patients during the acute phase of the disease. These samples were tested by PCR assays, and HAdV-3 genomes were detected in the samples from both patients. Additionally, HAdV-3 was directly isolated from the younger brother's fecal sample. Both patients were negative for serum neutralizing antibodies against HAdV-3 upon admission, but these antibodies were significantly elevated in both patients 2 weeks after their admission, suggesting that they underwent seroconversion. The patients' father and elder sister also developed clinical symptoms consistent with acute HAdV infection around the time that the twins were infected.

\section{Discussion}

Here, we have presented a case of 4-year-old monozygotic twins who sequentially developed KD in conjunction with HAdV-3 infection. There have been few case reports of monozygotic twins who developed KD simultaneously, and only two of these reports identified the trigger of KD (Table 2) [5-10].

It has recently been presumed that the etiology of $\mathrm{KD}$ combines genetic susceptibility and specific infection, both of which are essential for KD development. Patients with KD seem to have some genetic predisposition, and ethnic differences in the morbidity and familial aggregation of KD have been reported [11]. Some functional single-nucleotide polymorphisms (SNPs) of genes such as inositol 1,4,5-trisphosphate 3-kinase C (ITPKC) and caspase 3 (CAPS3) significantly increase susceptibility to $\mathrm{KD}[2,12,13]$.

HAdV, group A streptococcus, Staphylococcus, Bacillus cereus, and Yersinia have all been reported as triggering pathogens of $\mathrm{KD}$. In general, KD most commonly develops in infants, toddlers, and young children; adult patients are rarely reported [14]. Most children get infected with common pathogens, such as HAdV, during early childhood, so if these pathogens can trigger KD, this may partially explain the higher KD prevalence in children than that in adults.

HAdV infection itself could be one of the differential diagnoses of KD. HAdV infection also shows KD-like symptoms such as conjunctival injection, red cracked lips, and cervical lymphadenopathy. However, skin erythema and swollen red palms and soles followed by desquamation are distinctive features of KD. Additionally, a coronary lesion can allow the definitive diagnosis of KD. In our case, the younger brother's echocardiography revealed a dilation of the left circumflex artery, so we definitively diagnosed him with KD.

Several previous reports show that HAdV was detected by PCR in samples from the respiratory tract of patients with KD [15-17]. However, it is difficult to distinguish between latent and acute HAdV infection by 
Table 2 Previous reports of Kawasaki disease in monozygotic twins

\begin{tabular}{|c|c|c|c|c|c|c|c|c|}
\hline \multicolumn{3}{|l|}{ Author (country) } & \multirow{2}{*}{$\begin{array}{l}\text { Age } \\
\text { (month) }\end{array}$} & \multirow[t]{2}{*}{ Sex } & \multirow{2}{*}{$\begin{array}{l}\text { Interval } \\
\text { of onset }\end{array}$} & Twin A & Twin B & \multirow[t]{2}{*}{ Trigger } \\
\hline & & & & & & \multicolumn{2}{|c|}{ (Symptoms of KD/CAA ${ }^{\mathrm{a}}$ ) } & \\
\hline Fink HW. & 1985 & (USA) & 10 & female & same day & $6 /-$ & $6 /-$ & unknown \\
\hline Hoshino K, et al. & 1990 & (Japan) & 16 & female & same day & $5 /+$ & $5 /-$ & unknown \\
\hline Kuijpers TW, et al. & 2000 & (Netherlands) & 29 & female & 3 days & $6 /-^{a}$ & $5 /-$ & measles virus infection \\
\hline Ide $T$, et al. & 2007 & (Japan) & 13 & female & 1 day & $6 /-$ & $4 /-$ & measles-rubella vaccine \\
\hline Kottek A, et al. & 2011 & (USA) & 18 & male & 2 days & $5 /-$ & $3 /-$ & unknown \\
\hline Zhang $X$, et al. & 2013 & (China) & 2 & female & same day & $4 /+$ & $4 /-$ & unknown \\
\hline
\end{tabular}

CAA coronary artery abnormalities, a transient dilation

this method. Coincidental isolation of HAdV by PCR may also occur in some patients with KD. In our case, monozygotic twins simultaneously developed KD after acute HAdV-3 infection. HAdV-3 was detected in stool samples from both patients by PCR, and HAdV3 was directly isolated from the younger brother's stool sample. Additionally, serum neutralizing antibody to HAdV-3 was significantly elevated in both patients 2 weeks after admission, compared with undetectable levels upon admission. This sero-conversion suggests acute infection. Furthermore, the elevated serum IFN- $\gamma$ and IL-18 levels observed in these patients might also reflect a systemic inflammatory reaction against an acute viral infection. Therefore, we hypothesize that HAdV infection in children with a genetic susceptibility to KD may abnormally stimulate their innate immunity and evoke a cytokine storm leading to the development of KD. As acute infection can trigger $\mathrm{KD}, \mathrm{KD}$ may have self-limiting and acute-onset features.

\section{Conclusion}

Our report contributes further evidence that a specific response to a pathogen such as HAdV, combined with genetic susceptibility, plays an essential role in the development of $\mathrm{KD}$.

\section{Abbreviations \\ ALT: Alanine aminotransferase; AST: Aspartate aminotransferase; CRP: C - reactive protein; G-CSF: Granulocyte colony-stimulating factor; HAdV: Human adenovirus; HAdV-3: Human adenovirus type 3; IFN- $\gamma$ : Interferon- $\gamma$; IL- 18: Interleukin-18; IL-6: Interleukin-6; IL-8: Interleukin-8; IVIG: Intravenous immunoglobulin; KD: Kawasaki disease; sTNFR-1: Soluble tumor necrosis factor receptor 1; sTNFR-2: Soluble tumor necrosis factor receptor 2; TNF- a: Tumor necrosis factor a; WBC: White blood cells}

\section{Acknowledgements}

None

\section{Funding}

None of the authors have any sources of funding to declare in relation to this manuscript.

Availability of data and materials

Not applicable

\section{Authors' contributions}

SF wrote the first draft. SF, MF, and HK treated the patients. JA measured the serum cytokine levels. NH and TF performed virological analyses. SI is the overall supervisor of this study. All authors read and approved the final manuscript.

\section{Competing interests}

None of the authors have any financial or any non-financial competing interests to declare in relation to this manuscript.

\section{Consent for publication}

Consent has been given by the parents of these patients.

Ethics approval and consent to participate

Not applicable

\section{Publisher's note}

Springer Nature remains neutral with regard to jurisdictional claims in published maps and Institutional affiliations.

\section{Author details}

'Department of Pediatrics, Kawakita General Hospital, 1-7-3 Asagaya-kita, Suginami-ku, Tokyo, Japan. ${ }^{2}$ Department of Pediatrics, Graduate School of Medicine, Yokohama City University, 3-9 Fukuura, Kanazawa-ku, Yokohama, Japan. ${ }^{3}$ Department of Allergy and Immunology, National Center for Child Health and Development, 2-10-1 Okura, Setagaya-ku, Tokyo, Japan. ${ }^{4}$ Infectious Disease Surveillance Center, National Institute of Infectious Diseases, 1-23-1 Toyama, Shinjuku-ku, Tokyo, Japan.

Received: 7 March 2017 Accepted: 5 May 2017 Published online: 16 May 2017

\section{References}

1. Kawasaki T. Acute febrile mucocutaneous lymph node syndrome: clinical observations of 50 cases. Jpn J Allergy. 1967;16:178-222.

2. Onouchi Y, Tamari M, Takahashi A, Tsunoda T, Yashiro M, Nakamura Y, Yanagawa H, Wakui K, Fukushima Y, Kawasaki T, Nakamura Y, Hata A. A genomewide linkage analysis of Kawasaki disease: evidence for linkage to chromosome 12. J Hum Genet. 2007:52:179-90.

3. Kusuda T, Nakashima Y, Murata K, Kanno S, Nishio H, Saito M, Tanaka T, Yamamura K, Sakai Y, Takada H, Miyamoto T, Mizuno Y, Ouchi K, Waki K, Hara T. Kawasaki disease-specific molecules in the sera are linked to microbe-associated molecular patterns in the biofilms. PLoS One. 2014;20; 9(1)e113054.

4. Chang LY, Lu CY, Shao PL, Lee PI, Lin MT, Fan TY, Cheng AL, Kee WL, Hu J, Yeh SJ, Chang CC, Chiang BL, Wu MH, Huang LM. Viral infections associated with Kawasaki disease. J Formos Med Assoc. 2014;113(3):148-54.

5. Fink HW. Simultaneous Kawasaki disease in identical twins: case report. Va Med. 1985;112(4):248-51.

6. Hoshino K, Ogawa K, Kato K, Kan Z, Hoshino H. Monozygotic KD twin which had simultaneous onset and discordant giant aneurism. Jpn J Pediatr. 1990; 43:550-4.

7. Kuijpers TW, Herweijer TJ, Schölvinck L, Wertheim-Van Dillen PM, Van de Veer EM. Kawasaki disease associated with measles virus infection in a monozygotic twin. Pediatr Infect Dis J. 2000;19(4):350-3. 
8. Ide T, Minami T, Izumi G, Hama T, Miyawaki M, Yoshimasu T, Ban H, SUenaga T, Shibuta S, Takeuchi T, Suzuki H, Yoshikawa N, et al. Simultaneous onset of Kawasaki disease in monozygotic twins. Prog Med. 2007:27:1535-9.

9. Kottek A, Shimizu C, Burns JC. Kawasaki disease in monozygotic twins. Pediatr Infect Dis J. 2011;30(12):1114-6.

10. Zang X, Sun J, Zhai S, Yang S. Kawasaki disease in two sets of monozygotic twins: is the etiology genetic or environmental? Pak J Med Sci. 2013;29(1):227-30.

11. Uehara R, Yashiro M, Nakamura Y. Kawasaki disease in parents and children. Acta Pediatr. 2003;92:694-7.

12. Onouchi Y, Gunji T, Burns JC, Shimizu C, Newburger JW, Yashiro M, Nakamura Y, Yanagawa H, Wakui K, Fukushima Y, Kishi F, Hamamoto K, Terai M, Sato Y, Ouchi K, Saji T, Nariai A, Kaburagi Y, Yoshikawa T, Suzuki K, Tanaka T, Nagai T, Cho H, Fujino A, Sekine A, Nakamichi R, Tsunoda T, Tomisaku K, Nakamura Y, Hata A. ITPKC functional polymorphism associated with Kawasaki disease susceptibility and formation of coronary artery aneurysms. Nat Genet. 2008:40:35-42.

13. Onouchi Y, Ozaki K, Burns JC, Shimizu C, Hamada H, Honda T, Terai M, Honda A, Takeuchi T, Shibuta S, Suenaga T, Suzuki H, Higashi K, Yasukawa K, Suzuki Y, Sasago K, Kemmotsu Y, Takatsuki S, Saji T, Yoshikawa T, Nagai T, Hamamoto K, Kishi F, Ouchi K, Sato Y, Newburger JW, Baker AL, Shulman ST, Rowley AH, Yashiro M, Nakamura Y, Wakui K, Fukushima Y, Fujino A, Tsunoda T, Kawasaki T, Hata A, Nakamura Y, Tanaka T. Common variants in CASP3 confer susceptibility to Kawasaki disease. Hum Mol Genet. 2010;19: 2898-996.

14. Ueda Y, Kenzaka T, Noda A, Yamamoto Y, Masami M. Adult-onset Kawasaki disease (mucocutaneous lymph node syndrome) and concurrent Coxsackievirus A4 infection: a case report. Int Med Case Rep J. 2015;8:225-30.

15. Jaggi $\mathrm{P}$, Kajon AE, Mejias A, Ramilo O, Leber A. Human adenovirus infection in Kawasaki disease: a confounding bystander? Clin Infect Dis. 2013;56(1):65-6.

16. Song E, Kajon AE, Wang H, Salamon D, Texter K, Ramilo O, Leber A, Jaggi P. Clinical and Virologic characteristics may aid distinction of acute adenovirus disease from Kawasaki disease with incidental adenovirus detection. J Pediatr. 2016;170:325-30

17. Jordan-Villegas A, Chang ML, Ramilo O, Mejias A. Concomitant respiratory viral infections in children with Kawasaki disease. Pediatr Infect Dis. 2013;56:58-64.

\section{Submit your next manuscript to BioMed Central and we will help you at every step:}

- We accept pre-submission inquiries

- Our selector tool helps you to find the most relevant journal

- We provide round the clock customer support

- Convenient online submission

- Thorough peer review

- Inclusion in PubMed and all major indexing services

- Maximum visibility for your research

Submit your manuscript at www.biomedcentral.com/submit

Biomed Central 